\title{
Short communication: Flavor and flavor stability of cheese, rennet, and acid wheys
}

\author{
S. Smith, T. J. Smith, and M. A. Drake ${ }^{1}$ \\ Department of Food, Bioprocessing and Nutrition Sciences, Southeast Dairy Foods Research Center, North Carolina State University, \\ Raleigh 27695
}

\begin{abstract}
Dried whey ingredients are valuable food ingredients but potential whey sources are underutilized. Previous work has established flavor and flavor stability differences in Cheddar and Mozzarella wheys, but little work has compared these whey sources to acid or rennet wheys. The objective of this study was to characterize and compare flavor and flavor stability among cheese, rennet, and acid wheys. Full-fat and fat-free Cheddar, rennet and acid casein, cottage cheese, and Greek yogurt fluid wheys were manufactured in triplicate. Wheys were fat separated and pasteurized followed by compositional analyses and storage at $4^{\circ} \mathrm{C}$ for 48 h. Volatile compound analysis and descriptive sensory analysis were evaluated on all liquid wheys initially and after 24 and $48 \mathrm{~h}$. Greek yogurt whey contained almost no true protein nitrogen $(0.02 \% \mathrm{wt} / \mathrm{vol})$ whereas other wheys contained $0.58 \% \pm 0.4 \%(\mathrm{wt} / \mathrm{vol})$ true protein nitrogen. Solids and fat content were not different between wheys, with the exception of Greek yogurt whey, which was also lower in solids content than the other wheys (5.6 vs. $6.5 \%$ wt/vol, respectively). Fresh wheys displayed sweet aromatic and cooked milk flavors. Cheddar wheys were distinguished by diacetyl/buttery flavors, and acid wheys (acid casein, cottage cheese, and Greek yogurt) by sour aromatic flavor. Acid casein whey had a distinct soapy flavor, and acid and Greek yogurt wheys had distinct potato flavor. Both cultured acid wheys contained acetaldehyde flavor. Cardboard flavor increased and sweet aromatic and buttery flavors decreased with storage in all wheys. Volatile compound profiles were also distinct among wheys and changed with storage, consistent with sensory results. Lipid oxidation aldehydes increased in all wheys with storage time. Fat-free Cheddar was more stable than fullfat Cheddar over $48 \mathrm{~h}$ of storage. Uncultured rennet casein whey was the most stable whey, as exhibited
\end{abstract}

Received October 2, 2015.

Accepted January 20, 2016.

${ }^{1}$ Corresponding author: maryanne_drake@ncsu.edu by the lowest increase in lipid oxidation products over time. These results provide baseline information for the viability of processing underutilized wheys into valueadded ingredients.

Key words: acid whey, sweet whey, flavor, gas chromatography

\section{Short Communication}

When cheese or yogurt is produced by coagulating the casein from milk, the liquid byproduct is known as whey. Whey and whey protein powders are important ingredients but may contribute undesirable flavors to finished products (Wright et al., 2009; Evans et al., 2010; Oltman et al., 2015). The flavor of fluid whey changes based on cheese production parameters, including milk origin, heat treatment, bacterial starter cultures, coagulation method, and $\mathrm{pH}$ (Gallardo-Escamilla et al., 2005; Campbell et al., 2011a,b; Liaw et al., 2011). Pasteurization of fluid whey, storage, and fat removal also subsequently influence flavor (Liaw et al., 2010; Whitson et al., 2011). These effects on fluid whey flavor directly influence the flavor of any subsequent dried whey ingredient (Campbell et al., 2011b; Jervis et al., 2012, 2015). As such, flavor variability and flavor stability of fluid whey are important to maximize flavor quality of dried whey ingredients.

Whey is divided into 2 main categories: acid whey and sweet whey, although distinct differences also exist between cultured and rennet set wheys (Campbell et al., 2011b). Fresh sweet whey flavor has been characterized by the sensory terms sweet aromatic, cooked milky, and diacetyl/buttery (Gallardo-Escamilla et al., 2005; Liaw et al., 2010, 2011). Few studies have addressed the sensory properties of acid whey. Gallardo Escamilla et al. (2005) reported rancid and stale flavors in acid casein whey but the effect of storage time was not addressed so it is unclear if other confounding factors influenced the sensory properties reported. Storage of Cheddar and Mozzarella wheys increased cardboard flavor, which was directly sourced to increased volatile lipid oxidation compounds (Whitson et al., 2010; 
Campbell et al., 2011b; Liaw et al., 2011). Campbell et al. (2011b) demonstrated that these changes in lipid oxidation compounds were increased with cultured wheys compared with rennet set wheys and that differences documented among cultured wheys were attributed to differences with starter cultures.

Little work has addressed underutilized acid wheys such as cottage cheese and Greek yogurt wheys. A direct comparison of sweet and acid, and cultured and noncultured liquid wheys over storage time has yet to be studied and would facilitate additional applications for those products. The objective of this study was to evaluate the flavor and flavor stability of 6 different liquid wheys over $48 \mathrm{~h}$ of storage. The whey varieties evaluated were white Cheddar, fat-free white Cheddar, rennet casein (all sweet wheys), acid casein, Greek yogurt, and cottage cheese wheys (all acid wheys). This study serves as a baseline understanding of the sensory and stability characteristics of these 6 wheys and may determine potential uses for Greek yogurt whey.

The experiment was conducted over $2 \mathrm{~d}$. On d 1, 3 of the wheys were manufactured and on $\mathrm{d} 2$, the other 3 wheys were manufactured. One lot of milk was used for each replicate of all wheys. The order in which wheys were made on which days was randomized across all 3 replicates. Approximately $75 \mathrm{~L}$ of milk was used for each replicate of each whey. All wheys were manufactured in triplicate, and wheys were manufactured using standard procedures (Varnam and Sutherland, 1994; McAuliffe et al., 1999; Maragkoudakis et al., 2006; Campbell et al., 2011b). Raw bovine milk was obtained from the North Carolina State University Dairy Research and Education Unit (Raleigh). Wheys were manufactured from skim milk, except for Cheddar, which was made from whole milk. Skim milk was used because it is the milk source commonly used for these whey sources. Whey from regular (whole milk) uncolored Cheddar cheese milk has been previously characterized and served as a control (Liaw et al., 2010, 2011; Campbell et al., 2011b). Milk for wheys except Greek yogurt was HTST pasteurized at $72^{\circ} \mathrm{C}$ for 16 s using a plate heat exchanger (model T4 RGS-16/2; SPX Flow Technology, Greensboro, NC). For Greek yogurt whey, raw skim milk was heated to $95^{\circ} \mathrm{C}$ for 5 min in a water-jacketed pasteurization vat and then immediately cooled to $37^{\circ} \mathrm{C}$ using the same vat (model MPD1050, Micro Process Design, D\&F Equipment Co., McLeansville, NC). All wheys were subjected to fat separation and pasteurization at $63^{\circ} \mathrm{C}$ for $30 \mathrm{~min}$, followed by cooling to $10^{\circ} \mathrm{C}$ using a glycol bath. Cooled, pasteurized wheys were dispensed into autoclaved amber glass containers (VWR International, Radnor, PA) and stored at typical refrigeration temperatures $\left(4^{\circ} \mathrm{C}\right)$.
Wheys were sampled for immediate analysis and then after 24 and $48 \mathrm{~h}$ to determine the oxidative stability of each whey. These time points span the typical time that fluid product may be stored in whey processing $(0$ to $48 \mathrm{~h}$ ).

Cheddar and fat-free Cheddar were produced in the same manner: milk was heated to $31^{\circ} \mathrm{C}$ and was inoculated with mesophilic starter culture (Choozit MA 11, Danisco, New Century, NJ) at a rate of 50 direct culture units $/ 454 \mathrm{~kg}$ of milk. Calcium chloride was then added at $0.39 \mathrm{~mL} / \mathrm{kg}$ of milk $(50 \% \mathrm{wt} / \mathrm{vol}$, Dairy Connection Inc., Madison, WI). The milk was ripened for $60 \mathrm{~min}$ under constant agitation. Milk was then coagulated for 30 min with double-strength recombinant rennet (Dairy Connection), which was added at a rate of $0.09 \mathrm{~mL} /$ $\mathrm{kg}$ of milk. The coagulum was cut into approximately $2.5-\mathrm{cm}^{3}$ cubes and allowed to rest for $5 \mathrm{~min}$, followed by gradual heating to $39^{\circ} \mathrm{C}$ over the course of $30 \mathrm{~min}$ with gentle agitation. Cheddar and fat-free Cheddar wheys were then drained, fat separated, pasteurized, and held at $4^{\circ} \mathrm{C}$.

For cottage cheese whey manufacture, pasteurized skim milk was heated to $21^{\circ} \mathrm{C}$ and inoculated with mesophilic starter culture (F-DVS Fresco 1000-21, Chr. Hansen, Milwaukee, WI) at a rate of $5 \mathrm{~g} / 25 \mathrm{~L}$ of milk. After $30 \mathrm{~min}$, double-strength recombinant rennet (Dairy Connection) was added at a rate of 0.2 $\mathrm{mL} / 100 \mathrm{~L}$ of milk. The milk was then incubated for approximately 4 to $5 \mathrm{~h}$, until a $\mathrm{pH}$ of 4.6 was reached. Afterward, the curd was cut into $2.5-\mathrm{cm}^{3}$ cubes and allowed to rest for 10 to $15 \mathrm{~min}$. The curd was then heated gradually to $55^{\circ} \mathrm{C}$ over $90 \mathrm{~min}$, drained through a sieve, separated, and pasteurized.

For Greek yogurt whey, raw skim bovine milk was heated to $95^{\circ} \mathrm{C}$ for $5 \mathrm{~min}$ in a vat pasteurizer (model MPD1050, Micro Process Design, D\&F Equipment Co.), cooled to $40^{\circ} \mathrm{C}$, and inoculated with thermophilic starter cultures (DVS YF-L702, Chr. Hansen) at a rate of $1 \mathrm{~g} / 5 \mathrm{~L}$ of milk. The milk was then incubated at $40^{\circ} \mathrm{C}$ for $4 \mathrm{~h}$ until the $\mathrm{pH}$ reached 4.6. The coagulum and whey were then transferred to a plastic strainer lined with 2 layers of fine cheesecloth, and the whey was allowed to drain into a collection container for $16 \mathrm{~h}$ at $4^{\circ} \mathrm{C}$ followed by separation and pasteurization (Maragkoudakis et al., 2006).

Both acid and rennet casein were produced without the addition of starter culture. Acid casein whey was manufactured by addition of dilute $(1 N)$ hydrochloric acid (Sigma Aldrich, St. Louis, MO) at a rate of approximately $3.75 \mathrm{~L} / 75 \mathrm{~L}$ of skim milk to bring the $\mathrm{pH}$ to 4.6 . The milk was then heated to $50^{\circ} \mathrm{C}$. The whey was drained from the curd, fat separated, and pasteurized. Rennet casein whey was manufactured by heating skim 
milk to $29^{\circ} \mathrm{C}$ and adding double-strength recombinant rennet (Dairy Connection) at a rate of $0.09 \mathrm{~mL} / \mathrm{kg}$ of milk. The milk was then allowed to rest for $1 \mathrm{~h}$ before the curd was cut, and the whey was drained, separated, and pasteurized (Varnam and Sutherland, 1994).

Proximate analyses were conducted in triplicate. Total nitrogen and NPN were analyzed by Kjeldahl (AOAC International, 2000; method numbers 991.20; 33.2.11 and 991.21; 33.2.12). True protein nitrogen for each whey was determined by subtracting NPN from total $\mathrm{N}$; true protein nitrogen values were obtained by multiplying $\mathrm{N}$ values by a conversion factor of $\mathrm{N}$ $\times 6.38$ (Barbano and Lynch, 1992). Fat content was determined using Mojonnier fat extraction (AOAC International, 2007; method number 989.05), and total solids were determined using air oven drying (AOAC International, 2007; method number 990.20). The $\mathrm{pH}$ was measured on all wheys using a $\mathrm{pH}$ meter at all time points (model Symphony SB70P, VWR International) and titratable acidity was determined at all time points using AOAC International (1996; method number 947.05-1947). Sodium, potassium, calcium, and magnesium were determined by inductively coupled plasma spectrophotometry (ICP) by the North Carolina State University Analytical Services Laboratory (Raleigh). Lactose was measured using a method modified from Upreti et al. (2006); briefly, $100 \mu \mathrm{L}$ of each sample was extracted in $900 \mu \mathrm{L}$ of $0.013 \mathrm{~N} \mathrm{H}_{2} \mathrm{SO}_{4}$, vortexed, and centrifuged at $8,000 \times g$ for $5 \mathrm{~min}$. The top layer was removed and filtered using $0.45-\mu \mathrm{m}$ nylon syringe filters (VWR International). Twenty microliters of each sample was injected on the HPLC (Waters 1525 Binary Pump, Waters, Milford, MA) using an autosampler (Waters 2707 Autosampler) onto the column $(0.8 \mathrm{~mL} /$ min, $7 \mu \mathrm{m}, 300 \times 7.8 \mathrm{~mm}$ ion exclusion, Bio-Rad Labs, Richmond, CA, $55^{\circ} \mathrm{C}$ ). Each replicate of each whey was injected in duplicate. The temperature of the injector was $4^{\circ} \mathrm{C}$ and a refractive index detector (Waters 2414 Refractive Index Detector, $30^{\circ} \mathrm{C}$ ) was use. A standard curve was created for lactose. Standards were obtained from Sigma Aldrich.

Descriptive analysis was performed on the wheys at each time point. A trained panel $(\mathrm{n}=8,6$ females, 2 males, ages 22 to $47 \mathrm{yr}$ ), with $>100 \mathrm{~h}$ of experience using an established sensory lexicon for fluid whey and whey ingredients and the Spectrum method, evaluated the wheys (Meilgaard et al., 2007; Liaw et al., 2010, 2011). Wheys were dispensed into lidded soufflé cups and evaluated at $15^{\circ} \mathrm{C}$. Each panelist evaluated each whey in triplicate. Compusense Five (version 5.2; Compusense, Guelph, ON, Canada) was used for data collection.

At each time point, selected volatile compounds were extracted from wheys using headspace solid-phase microextraction (SPME) and GC-MS. The methods were modified from Liaw et al. (2010) and Campbell et al. (2011b). All injections were made on an Agilent 7820A gas chromatograph with 5975 inert MSD with a ZB-5ms (5\% diphenyl/95\% dimethylsiloxane; $30 \mathrm{~m} \times$ $0.25 \mathrm{~mm}$ internal diameter $\times 0.25 \mu \mathrm{m})$ column $(\mathrm{Phe}-$ nomenex, Torrance, CA). Samples were injected using a CTC Analytics CombiPal Autosampler (CTC Analytics, Alexandria, VA). Volatile analysis samples were prepared in triplicate by adding $5 \mathrm{~mL}$ of liquid whey to 20-mL amber SPME vials (MicroLiter Analytical Supplies Inc., Suwanee, GA), followed by addition of $0.5 \mathrm{~g}$ of $\mathrm{NaCl}$ and internal standard $(10 \mu \mathrm{L}$ of $81 \mathrm{ppm}$ 2-methyl-3-heptanone in methanol; Sigma Aldrich, St. Louis, MO) to each vial. Vials were frozen at $-80^{\circ} \mathrm{C}$ and added to the autosampler 3 at a time, 60 to 120 min before injection to reduce off-flavor formation due to storage time but providing ample time for the samples to thaw. Each vial was equilibrated for $25 \mathrm{~min}$ at $40^{\circ} \mathrm{C}$ with 4 -s pulse agitation at $250 \mathrm{rpm}$. All analyses for each replicate were performed using the same divinylbenzene (DVB)/Carboxen/polydimethylsiloxane (PDMS) 1-cm SPME fiber (Supelco, Bellefonte, PA). The fiber was exposed in the sample vials at a depth of $3.1 \mathrm{~cm}$ for $40 \mathrm{~min}$ before it was retracted and injected at $5 \mathrm{~cm}$ for $5 \mathrm{~min}$ into the GC inlet. Single ion monitoring was used to search for selected volatile flavor compounds based on previous studies (Karagül-Yüceer et al., 2003b; Gallardo-Escamilla et al., 2005; Campbell et al., 2011b). Scanning from 35 to $350 \mathrm{~m} / z$ to evaluate a mass collection of all volatiles was also simultaneously performed.

The GC method used an initial oven temperature of $40^{\circ} \mathrm{C}$, increased to $250^{\circ} \mathrm{C}$ after $3 \mathrm{~min}$ at a rate of $10^{\circ} \mathrm{C} / \mathrm{min}$, and held for $5 \mathrm{~min}$. The SPME fibers were introduced into the split/splitless injector at $250^{\circ} \mathrm{C}$, and a constant flow rate of $1 \mathrm{~mL} / \mathrm{min}$ was used. The purge time was set at $1 \mathrm{~min}$. The MS transfer line was maintained at $250^{\circ} \mathrm{C}$ with the quad at $150^{\circ} \mathrm{C}$ and source at $250^{\circ} \mathrm{C}$. Identification of compounds was performed using the National Institute of Standards and Technology (NIST) 2005 library of spectra (NIST, 2005) and comparison of spectra of authentic standards injected under identical conditions. Relative abundance for each compound was determined using the calculated recovery of the internal standard concentration to determine relative concentrations of each compound. An alkane series (Sigma Aldrich, Milwaukee, WI) was used to calculate retention indices (Vandendool and Kratz, 1963).

Selected volatile free fatty acids were also analyzed using SPME and GC-MS for each time point using a modified method from Tomaino et al. (2004). All injections were made on an Agilent 6890N with 5973 inert MSD with a ZB-FFAP $\mathrm{ms}(30 \mathrm{~m} \times 0.25 \mathrm{~mm}$ internal 
diameter $\times 0.25 \mu \mathrm{m})$ column (Phenomenex). Samples were injected using a CTC Analytics CombiPal Autosampler (CTC Analytics). Volatile analysis samples were prepared in triplicate by adding $5 \mathrm{~mL}$ of liquid whey to 20-mL amber SPME vials (MicroLiter Analytical Supplies Inc.) followed by addition of internal standard $(40 \mu \mathrm{L}$ of $317 \mathrm{ppm}$ heptadecanoic acid in ether; Sigma Aldrich) to each vial. Vials were frozen at $-80^{\circ} \mathrm{C}$ and added to the autosampler 3 at a time, 60 to 120 min before injection to reduce off-flavor formation due to storage time but providing ample time for the samples to thaw. Each vial was equilibrated for $10 \mathrm{~min}$ at $100^{\circ} \mathrm{C}$ with 4 -s pulsed agitation at $250 \mathrm{rpm}$ before 40-min fiber exposure (22-mm vial penetration) of a 30$\mu \mathrm{m}$ polydimethylsiloxane fiber (Supelco). The fiber was then retracted and injected at $5 \mathrm{~cm}$ for $10 \mathrm{~min}$ into the GC inlet. The GC method used an internal temperature of $100^{\circ} \mathrm{C}$ for 2 min with a ramp rate of $10^{\circ} \mathrm{C} / \mathrm{min}$ up to $245^{\circ} \mathrm{C}$ and held for $13.5 \mathrm{~min}$. Helium flow rate was $1 \mathrm{~mL} / \mathrm{min}$, and the fiber was injected into the split/ splitless injector at $250^{\circ} \mathrm{C}$. Scanning from 35 to 350 $\mathrm{m} / \mathrm{z}$ to evaluate a mass collection of all volatiles was performed. Identification of compounds was performed using the NIST 2005 library of spectra and comparison of spectra of authentic standards injected under identical conditions. Relative abundance for each compound was determined using the calculated recovery of the internal standard concentration to determine relative concentrations of each compound.

One-way ANOVA with means separation was conducted on proximate analysis results, and 2-way ANOVA (whey type $\times$ time) with means separation was conducted for sensory and volatile compounds. Principal component analysis was also conducted on sensory and volatile data to visualize differences. Statistical analyses were conducted with XLSTAT (version 2013.5.03; Addinsoft, New York, NY).

Proximate analysis results were consistent with previous studies (Kosikowski and Mistry, 1997; GallardoEscamilla et al., 2005; Campbell et al., 2011b) with the addition of cottage cheese whey and Greek yogurt whey. All wheys contained $6.5 \% \pm 0.4 \%$ solids with the exception of Greek yogurt whey, which contained $5.6 \%$ solids $(P<0.05)$. The lower solids content in the Greek yogurt whey was attributed to its low true protein content $(0.02 \%)$. The low true protein content of Greek whey was likely due to the high temperatures applied to the milk for production of Greek yogurt. The high heat treatment denatures the whey proteins, causing them to unfold and contribute to gel structure. As such, whey proteins are retained with the yogurt mass. This finding suggests that Greek yogurt whey is likely not a viable source of protein for concentrated whey protein applications. Sweet wheys did not differ in true protein content, averaging $0.58 \% \pm 0.4 \%$. Acid casein and cottage cheese wheys were not different from each other, averaging $0.48 \% \pm 0.4 \%(P>0.05)$, although acid casein whey was lower $(P<0.05)$ in true protein compared with sweet wheys ( 0.45 vs. $0.58 \%$ respectively). The lower true protein content of these acid wheys was attributed to their $\mathrm{pH}$ being closer to the isoelectric points of the whey proteins $\alpha$-LA and $\beta-\mathrm{LG}$ (4.2 and 5.1, respectively), which would cause them to be more likely to associate with the casein micelles and be retained with the curd (Vasbinder and de Kruif, 2003). Values of NPN were also calculated for all wheys. Cottage cheese whey contained $0.053 \%$ NPN; Cheddar, Greek yogurt, rennet casein, and fat-free Cheddar wheys were not different $(P>0.05)$ in NPN $(0.038 \pm 0.002 \%)$, and acid casein contained $0.026 \%$ NPN. Milk typically contains 0.025 to $0.028 \%$ NPN. Wheys that are produced from cheeses using rennet (cottage, Cheddars, and rennet casein) retain glycomacropeptide in the NPN fraction, thus increasing the NPN value of these wheys (Turhan and Etzel, 2004). Hill et al. (1985) documented higher NPN values in cultured, low $\mathrm{pH}$ wheys than in high $\mathrm{pH}$ wheys and attributed the effects to proteolysis caused by the lactic culture during the longer fermentation time. This would explain why Greek yogurt whey was higher in NPN than acid whey, even though neither contained rennet, and why NPN in cottage cheese was higher than that in Cheddar and rennet casein, given that all 3 of these wheys used rennet.

Fat content did not differ among all wheys, averaging $0.012 \% \pm 0.008 \%(P>0.05)$. The $\mathrm{pH}(6.5 \pm 0.05$ and $4.58 \pm 0.12$ for sweet and acid wheys, respectively) and titratable acidity $(0.15 \pm 0.03 \%$ for sweet wheys, $1.0 \%$ for cottage and Greek yogurt, and $0.72 \%$ for acid casein wheys) did not increase over storage $(P>$ $0.05)$, indicating that no microbial growth occurred during storage. Lactose concentration was not different between sweet wheys and acid casein whey, averaging $5.55 \% \pm 0.15 \%(P>0.05)$. Greek yogurt whey and cottage whey contained lower levels of lactose (3.79 and $3.25 \%$ respectively; $P<0.05$ ). This is due to the long fermentation times of these 2 wheys, which give the lactic acid bacteria more time to convert lactose to lactic acid (Kandler, 1983). Minor differences between wheys for sodium, potassium, and magnesium were observed (Table 1); however, large differences in calcium were documented between sweet wheys and acid wheys $(0.35 \% \pm 0.04 \%$ and $1.18 \% \pm 0.04 \%$ respectively; $P$ $<0.05)$. The large difference in calcium was due to the method of setting the curd. In sweet wheys, rennet is used, which causes calcium caseinates to form, thus binding the calcium. In the acid-precipitated wheys, 
ionized (soluble) calcium is formed, which favors the whey rather than binding to the curd (Wong et al., 1978; Hill et al., 1985).

Consistent with previous studies, sensory differences were documented between sweet and acid wheys, and between cultured and noncultured wheys (GallardoEscamilla et al., 2005; Campbell et al., 2011a,b). The main effects on whey flavor were whey type and storage time (Table 2). Sweet wheys were characterized by sweet aromatic and cooked milky flavors and sweet tastes. Greek yogurt, cottage cheese, and acid casein wheys were characterized by sour aromatic flavor and sour and umami tastes. They also had low intensities of cooked milky flavor and sweet taste. Greek yogurt and acid wheys contained a distinct potato/brothy flavor. Greek yogurt and cottage cheese wheys also had distinct acetaldehyde flavor and higher aroma intensities compared with other wheys. Acid casein was the only whey to display a soapy flavor initially. Little work has documented flavors of Greek yogurt, acid casein, and cottage wheys, although many of the predominant flavors in these types of wheys (potato, sour aromatic, acetaldehyde, free fatty acid, and soapy) are flavors documented in cottage cheese and Greek yogurt (Drake et al., 2009; Desai et al., 2013).

Off-flavors in wheys were expected to increase due to lipid oxidation occurring during storage. Several studies have documented these changes in Cheddar, Mozzarella, and rennet-set wheys (Campbell et al., 2011b; Liaw et al., 2011), although no work has been done on the flavor of acid whey during storage. Fullfat Cheddar whey contained the highest intensities of cardboard flavor among sweet wheys following $48 \mathrm{~h}(P$ $<0.05$; Table 2, Figure 1). Acid casein contained the highest intensities of cardboard flavor initially and after $48 \mathrm{~h}(P<0.05)$. Fat-free Cheddar whey had the same amount of cardboard flavor as full-fat Cheddar whey initially but had a smaller increase in cardboard flavor than full-fat Cheddar whey. This is likely due to less free fat in the skim milk capable of oxidizing during the cheesemaking process. Lipid oxidation initiates during the cheesemaking procedure (Campbell et al., 2011b).

Table 1. Mineral analysis of wheys

\begin{tabular}{lccll}
\hline Sample & $\begin{array}{c}\mathrm{Ca} \\
(\mathrm{g} / \mathrm{L})\end{array}$ & $\begin{array}{c}\mathrm{K} \\
(\mathrm{g} / \mathrm{L})\end{array}$ & $\begin{array}{c}\mathrm{Mg} \\
(\mathrm{g} / \mathrm{L})\end{array}$ & $\begin{array}{c}\mathrm{Na} \\
(\mathrm{g} / \mathrm{L})\end{array}$ \\
\hline Acid & $1.16^{\mathrm{a}}$ & $1.40^{\mathrm{a}}$ & $0.11^{\mathrm{a}}$ & $0.41^{\mathrm{bc}}$ \\
Cottage & $1.15^{\mathrm{a}}$ & $1.34^{\mathrm{b}}$ & $0.10^{\mathrm{a}}$ & $0.49^{\mathrm{a}}$ \\
Greek & $1.23^{\mathrm{a}}$ & $1.47^{\mathrm{a}}$ & $0.11^{\mathrm{a}}$ & $0.44^{\mathrm{ab}}$ \\
Fat-free Cheddar & $0.31^{\mathrm{b}}$ & $1.18^{\mathrm{b}}$ & $0.06^{\mathrm{c}}$ & $0.34^{\mathrm{c}}$ \\
Cheddar & $0.40^{\mathrm{b}}$ & $1.35^{\mathrm{ab}}$ & $0.08^{\mathrm{b}}$ & $0.42^{\mathrm{ab}}$ \\
Rennet & $0.35^{\mathrm{b}}$ & $1.44^{\mathrm{a}}$ & $0.08^{\mathrm{b}}$ & $0.42^{\mathrm{ab}}$ \\
\hline
\end{tabular}

\footnotetext{
${ }^{\mathrm{a}-\mathrm{c}}$ Means in the same column not sharing a common superscript are
} different $(P<0.05)$.
Efficient fat removal from whey lessens the amount of fat available to oxidize, therefore reducing the overall content of lipid oxidation products, but will not eliminate it (Liaw et al., 2011). Cheddar whey from whole milk likely had greater initiation of lipid oxidation due to the higher amounts of fat present in the cheese milk. All wheys increased in cardboard flavors, and all sweet wheys decreased in cooked milky and sweet aromatic flavors over storage time $(P<0.05)$. Due to the lack of starter culture, rennet casein whey was the most stable with the smallest increase in cardboard flavors after $48 \mathrm{~h}$ and the lowest initial levels of lipid oxidation compounds. This is consistent with previous work performed by Campbell et al. (2011b), who demonstrated that lipid oxidation was accelerated with the addition of starter culture compared with whey without starter culture.

Volatile compound analysis results were consistent with sensory results (Table 3, Figure 2). Aldehydes including hexanal, heptanal, octanal, and nonanal have been attributed to cardboard flavor in liquid whey (Karagül-Yüceer et al., 2003a,b; Gallardo-Escamilla et al., 2005; Liaw et al., 2010; Whitson et al., 2010; Campbell et al., 2011b). Rennet casein whey had the lowest quantity of volatile aldehydes at all time points, consistent with sensory profiles $(P<0.05)$. Full-fat Cheddar whey contained the highest levels of volatile aldehydes of the sweet wheys after $48 \mathrm{~h}$. Fat-free Cheddar contained lower levels of the lipid oxidation compounds hexanal and heptanal after $48 \mathrm{~h}$ than did full-fat Cheddar whey. All wheys had lipid oxidation compounds at time 0, although uncultured sweet and acid wheys had lower initial levels of lipid oxidation than cultured sweet and acid wheys respectively, consistent with the report by Campbell et al. (2011b) indicating that lipid oxidation was accelerated by the addition of starter culture. Sweet wheys and uncultured acid whey had low initial levels of volatile aldehydes, and increased levels of these compounds after $48 \mathrm{~h}$ (Table 3, Figure 2). Cottage cheese and Greek yogurt wheys had the highest levels of aldehydes initially, and cottage cheese whey displayed the highest increase of volatile aldehydes between time 0 and $48 \mathrm{~h}(P<0.05)$. Acid casein whey also increased in volatile aldehydes over $48 \mathrm{~h}(P<0.05)$, with the largest increases in both acid casein and cottage cheese wheys occurring between 24 and $48 \mathrm{~h}$. Greek yogurt whey was fairly stable and did not increase in volatile aldehydes as much as other acid wheys over storage $(P>0.05)$, possibly due to the $16 \mathrm{~h}$ required for manufacture by straining. This whey was already "older" or "stored" upon collection. Because most commercial Greek whey is manufactured by centrifugation, these storage stability results may not be indicative of current commercial Greek whey. 
Table 2. Means separations for sensory attributes with significant F-statistics and interactions from descriptive sensory analysis of liquid wheys (whey type $\times$ time)

\begin{tabular}{|c|c|c|c|c|c|c|c|c|c|c|c|}
\hline Item & $\begin{array}{c}\text { Aroma } \\
\text { intensity }\end{array}$ & Cardboard & $\begin{array}{l}\text { Potato } \\
\text { brothy }\end{array}$ & $\begin{array}{c}\text { Cooked } \\
\text { milky }\end{array}$ & Acetaldehyde & $\begin{array}{c}\text { Sour } \\
\text { aromatic }\end{array}$ & $\begin{array}{c}\text { Sweet } \\
\text { aromatic }\end{array}$ & $\begin{array}{l}\text { Free fatty } \\
\text { acid/soapy }\end{array}$ & Sweet & Umami & Sour \\
\hline \multicolumn{12}{|l|}{ Whey } \\
\hline Acid & $2.0^{\mathrm{bc}}$ & $2.2^{\mathrm{a}}$ & $1.1^{\mathrm{a}}$ & $1.0^{\mathrm{c}}$ & $\mathrm{ND}^{2}$ & $0.5^{\mathrm{b}}$ & ND & $1.1^{\mathrm{a}}$ & $1.4^{\mathrm{b}}$ & $1.8^{\mathrm{a}}$ & $1.5^{\mathrm{b}}$ \\
\hline Greek & $2.1^{\mathrm{ab}}$ & $1.2^{\mathrm{c}}$ & $1.1^{\mathrm{a}}$ & $1.5^{\mathrm{b}}$ & $1.2^{\mathrm{a}}$ & $1.7^{\mathrm{a}}$ & ND & ND & $1.2^{\mathrm{b}}$ & $2.2^{\mathrm{a}}$ & $2.1^{\mathrm{a}}$ \\
\hline Cottage & $2.3^{\mathrm{a}}$ & $1.2^{\mathrm{c}}$ & ND & $1.6^{\mathrm{b}}$ & $1.3^{\mathrm{a}}$ & $1.6^{\mathrm{a}}$ & ND & ND & $1.3^{\mathrm{b}}$ & $1.9^{\mathrm{a}}$ & $1.8^{\mathrm{ab}}$ \\
\hline Fat-free Cheddar & $1.9^{\mathrm{c}}$ & $1.5^{\mathrm{b}}$ & ND & $2.4^{\mathrm{a}}$ & ND & ND & $1.0^{\mathrm{b}}$ & ND & $2.0^{\mathrm{a}}$ & $0.9^{\mathrm{bc}}$ & ND \\
\hline Cheddar & $2.1^{\mathrm{bc}}$ & $1.4^{\mathrm{b}}$ & ND & $2.5^{\mathrm{a}}$ & ND & ND & $1.2^{\mathrm{a}}$ & ND & $1.8^{\mathrm{a}}$ & $1.3^{\mathrm{b}}$ & $0.5^{\mathrm{c}}$ \\
\hline Rennet & $2.0^{\mathrm{bc}}$ & $1.2^{\mathrm{c}}$ & ND & $2.7^{\mathrm{a}}$ & ND & ND & $0.8^{\mathrm{b}}$ & ND & $2.0^{\mathrm{a}}$ & $0.7^{\mathrm{c}}$ & ND \\
\hline \multicolumn{12}{|l|}{ Time (h) } \\
\hline 0 & 2.1 & $1.1^{\mathrm{c}}$ & ND & $2.2^{\mathrm{a}}$ & 0.5 & 0.7 & 0.7 & ND & 1.7 & 1.5 & 1.0 \\
\hline 24 & 2.1 & $1.5^{\mathrm{b}}$ & 0.5 & $1.8^{\mathrm{b}}$ & 0.5 & 0.9 & ND & ND & 1.6 & 1.6 & 1.1 \\
\hline 48 & 2.0 & $1.8^{\mathrm{a}}$ & 0.5 & $1.7^{\mathrm{b}}$ & $\mathrm{ND}$ & 0.7 & ND & ND & 1.6 & 1.3 & 0.9 \\
\hline \multicolumn{12}{|l|}{ Interaction (whey $\times$ time) } \\
\hline Acid $\times$ Time- 0 & $1.9^{\mathrm{cd}}$ & $2.0^{\mathrm{bc}}$ & $1.2^{\mathrm{a}}$ & $1.0^{\mathrm{gh}}$ & ND & ND & ND & $0.8^{\mathrm{b}}$ & $1.3^{\operatorname{defgh}}$ & $1.7^{\mathrm{bcd}}$ & $1.5^{\mathrm{bc}}$ \\
\hline Acid $\times$ Time- 24 & $1.9^{\mathrm{cd}}$ & $2.0^{\mathrm{bc}}$ & $0.8^{\mathrm{a}}$ & $1.2^{\text {fgh }}$ & ND & $0.7^{\text {cde }}$ & ND & $1.2^{\mathrm{a}}$ & $1.5^{\mathrm{def}}$ & $1.8^{\mathrm{bcd}}$ & $1.5^{\mathrm{cd}}$ \\
\hline Acid $\times$ Time- 48 & $2.2^{\mathrm{abc}}$ & $2.7^{\mathrm{a}}$ & $1.3^{\mathrm{a}}$ & $0.8^{\mathrm{h}}$ & ND & $0.6^{\text {cde }}$ & ND & $1.3^{\mathrm{a}}$ & $1.3^{\mathrm{efgh}}$ & $1.8^{\mathrm{bcd}}$ & $1.6^{\mathrm{abc}}$ \\
\hline Greek $\times$ Time- 0 & $2.1^{\text {bcd }}$ & $0.7^{\mathrm{j}}$ & $0.8^{\mathrm{a}}$ & $1.7^{\mathrm{d}}$ & $1.2^{\mathrm{ab}}$ & $1.8^{\mathrm{ab}}$ & ND & ND & $1.2^{\mathrm{fgh}}$ & $2.4^{\mathrm{abc}}$ & $2.2^{\mathrm{abc}}$ \\
\hline Greek $\times$ Time-24 & $2.3^{\mathrm{ab}}$ & $1.3^{\mathrm{efg}}$ & $1.4^{\mathrm{a}}$ & $1.3^{\mathrm{efg}}$ & $1.5^{\mathrm{a}}$ & $2.0^{\mathrm{ab}}$ & ND & ND & $1.1^{\text {gh }}$ & $2.5^{\mathrm{ab}}$ & $2.3^{\mathrm{a}}$ \\
\hline Greek $\times$ Time- 48 & $2.0^{\mathrm{bcd}}$ & $1.6^{\text {def }}$ & $1.2^{\mathrm{a}}$ & $1.5^{\mathrm{def}}$ & $0.9^{\mathrm{b}}$ & $1.4^{\mathrm{abc}}$ & ND & ND & $1.4^{\text {defgh }}$ & $1.7^{\mathrm{bcd}}$ & $1.7^{\mathrm{abc}}$ \\
\hline Cottage $\times$ Time -0 & $2.5^{\mathrm{a}}$ & $0.6^{\mathrm{j}}$ & ND & $1.7^{\mathrm{d}}$ & $1.6^{\mathrm{a}}$ & $2.1^{\mathrm{a}}$ & ND & ND & $1.1^{\mathrm{h}}$ & $2.7^{\mathrm{a}}$ & $2.3^{\mathrm{ab}}$ \\
\hline Cottage $\times$ Time -24 & $2.4^{\mathrm{ab}}$ & $1.2^{\text {ghi }}$ & ND & $1.6^{\mathrm{de}}$ & $1.0^{\mathrm{b}}$ & $1.3^{\mathrm{bcd}}$ & ND & ND & $1.5^{\operatorname{defg}}$ & $1.7^{\mathrm{cd}}$ & $1.6^{\mathrm{abc}}$ \\
\hline Cottage $\times$ Time- 48 & $2.1^{\mathrm{bc}}$ & $1.7^{\mathrm{cd}}$ & ND & $1.4^{\mathrm{defg}}$ & $1.2^{\mathrm{ab}}$ & $1.4^{\mathrm{abc}}$ & ND & $0.5^{\mathrm{b}}$ & $1.4^{\text {defgh }}$ & $1.4^{\mathrm{de}}$ & $1.5^{\mathrm{cd}}$ \\
\hline Fat-free Cheddar $\times$ Time- 0 & $2.1^{\text {bed }}$ & $1.2^{\text {fghi }}$ & ND & $2.9^{\mathrm{ab}}$ & ND & ND & $1.3^{\mathrm{b}}$ & ND & $2.2^{\mathrm{a}}$ & $0.7^{\mathrm{e}}$ & ND \\
\hline Fat-free Cheddar $\times$ Time- 24 & $2.0^{\mathrm{cd}}$ & $1.6^{\mathrm{de}}$ & ND & $2.3^{\mathrm{c}}$ & ND & $0.6^{\mathrm{de}}$ & $0.6^{\mathrm{d}}$ & ND & $1.7^{\mathrm{bcd}}$ & $1.4^{\mathrm{de}}$ & $0.6^{\mathrm{e}}$ \\
\hline Fat-free Cheddar $\times$ Time -48 & $1.7^{\mathrm{d}}$ & $1.3^{\mathrm{efg}}$ & ND & $2.6^{\mathrm{bc}}$ & ND & ND & $1.0^{\mathrm{bc}}$ & ND & $2.0^{\mathrm{ab}}$ & $0.7^{\mathrm{e}}$ & ND \\
\hline Cheddar $\times$ Time -0 & $2.1^{\text {bcd }}$ & $0.9^{\mathrm{hij}}$ & ND & $3.1^{\mathrm{a}}$ & ND & ND & $2.0^{\mathrm{a}}$ & ND & $2.2^{\mathrm{a}}$ & $0.7^{\mathrm{e}}$ & ND \\
\hline Cheddar $\times$ Time -24 & $2.1^{\mathrm{bc}}$ & $1.4^{\mathrm{efg}}$ & ND & $2.3^{\mathrm{c}}$ & ND & $0.7^{\text {cde }}$ & $1.0^{\mathrm{bc}}$ & ND & $1.6^{\text {cde }}$ & $1.6^{\mathrm{d}}$ & $0.7^{\mathrm{de}}$ \\
\hline Cheddar $\times$ Time -48 & $2.1^{\mathrm{bc}}$ & $2.1^{\mathrm{b}}$ & ND & $2.2^{\mathrm{cd}}$ & ND & $0.5^{\mathrm{e}}$ & $0.7^{\mathrm{cd}}$ & ND & $1.7^{\mathrm{bcd}}$ & $1.6^{\mathrm{d}}$ & $0.7^{\mathrm{e}}$ \\
\hline Rennet $\times$ Time- 0 & $2.2^{\mathrm{abc}}$ & $0.9^{\mathrm{ij}}$ & ND & $3.1^{\mathrm{a}}$ & ND & ND & $0.8^{\mathrm{cd}}$ & ND & $2.0^{\mathrm{abc}}$ & $0.7^{\mathrm{e}}$ & ND \\
\hline Rennet $\times$ Time-24 & $1.9^{\mathrm{cd}}$ & $1.2^{\mathrm{fgh}}$ & ND & $2.7^{\mathrm{bc}}$ & ND & ND & $0.9^{\mathrm{cd}}$ & ND & $2.0^{\mathrm{ab}}$ & $0.7^{\mathrm{e}}$ & ND \\
\hline Rennet $\times$ Time -48 & $1.8^{\mathrm{d}}$ & $1.5^{\operatorname{defg}}$ & ND & $2.3^{\mathrm{c}}$ & ND & ND & $0.7^{\mathrm{cd}}$ & ND & $2.1^{\mathrm{a}}$ & $0.7^{\mathrm{e}}$ & ND \\
\hline
\end{tabular}

D. ${ }^{\mathrm{a}-\mathrm{j}}$ Means in the same column not sharing a common superscript are different $(P<0.05)$.

政- $\quad{ }^{1}$ Attributes were scored using a 0-15 point universal spectrum scale (Meilgaard et al., 2007). Fluid whey attributes fall between 0 and 3 on this scale (Liaw et al., 2010, 2011;

() Campbell et al., 2011b).

จे Not detected. 
The distinct potato/brothy flavor detected in Greek yogurt was likely due to elevated levels of methional, which is a Strecker degradation product formed by the interaction of the amino acid methionine with heatinitiated Maillard reaction intermediates. Methional has been identified and documented in fluid Cheddar whey and whey protein concentrates or isolates using gas chromatography-olfactometry and solvent-assisted flavor evaporation but was not positively identified in this study by headspace (SPME) analysis (Carunchia Whetstine et al., 2005; Liaw et al., 2011). Cottage cheese and Greek yogurt wheys were the only wheys containing acetaldehyde, also consistent with sensory results.

Volatile free fatty acid results were also consistent with sensory results (Table 4). Compared with the sweet wheys, the acid wheys contained higher levels of all volatile free fatty acids, consistent with higher levels of sour aromatic flavors and sour taste. Volatile free fatty acids in acid wheys did not increase over time $(P$ $<0.05)$. Cottage whey contained the highest levels of decanoic and dodecanoic acids, which have been documented to contribute to soapy flavor (Mahajan et al., 2004).

Collectively, these results are consistent with previous studies but also contribute new findings. GallardoEscamilla et al. (2005) noted that different volatile compound compositions determined most of the distinct sensory attributes of Cheddar, acid, and rennet casein wheys. Those authors did not evaluate or account for effects of storage on flavor nor did they evaluate lipid oxidation volatiles, which are primarily responsible for off-flavors in whey and dried whey ingredients. Campbell et al. (2011b) and Liaw et al. (2011) reported increases in aldehydes during $4^{\circ} \mathrm{C}$ storage concurrent with increased off-flavors in liquid whey, although only Cheddar and Mozzarella wheys were evaluated. Campbell et al. (2011b) later reported that wheys made from mesophilic Cheddar starter cultures contained higher levels of volatile aldehydes, and more off-flavors than wheys made with thermophilic Mozzarella starter cultures. Greek yogurt whey was the only whey in the

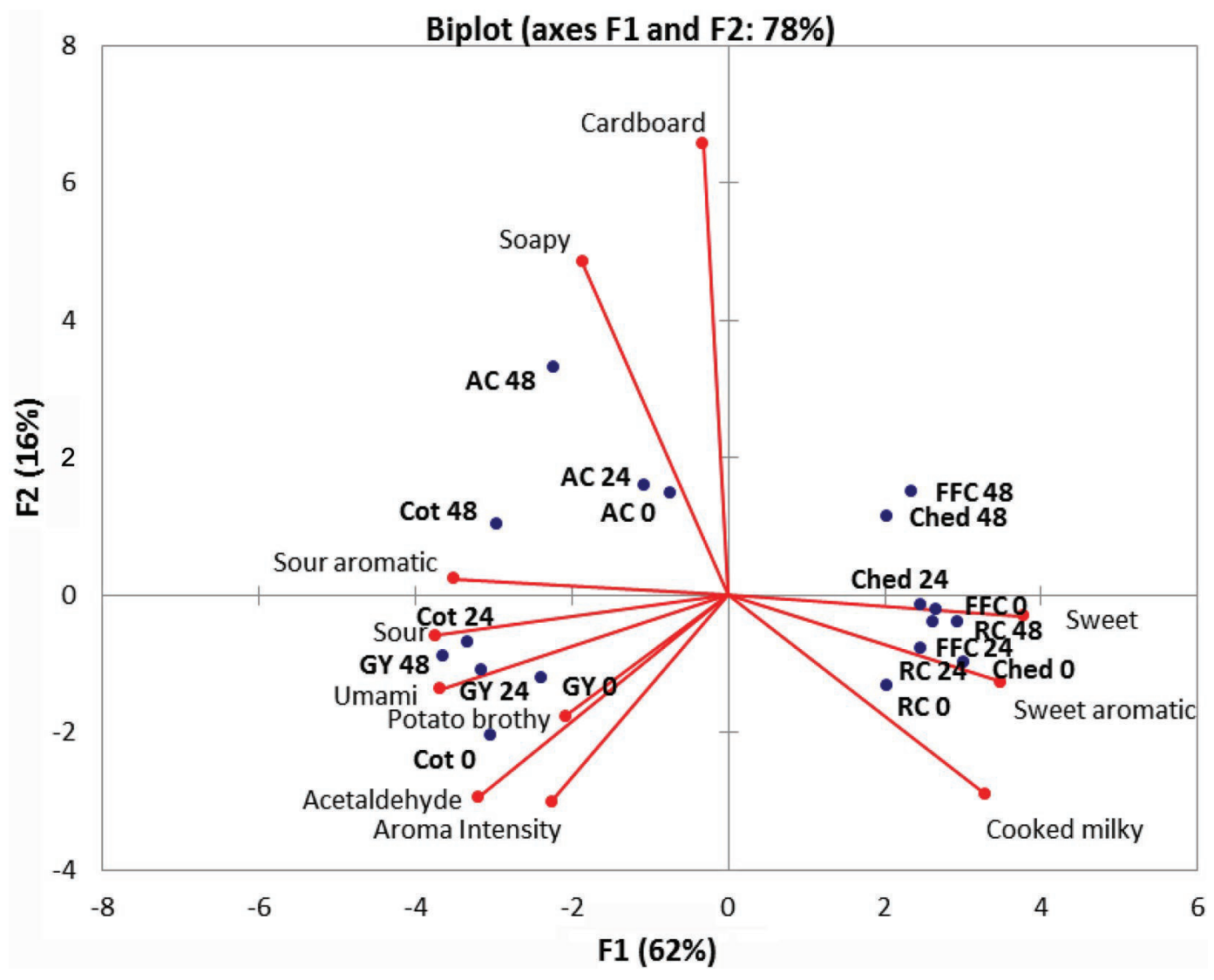

Figure 1. Principal component analysis biplot of descriptive analysis of liquid wheys: cottage cheese (Cot), Greek yogurt (GY), acid casein (AC), Cheddar cheese (Ched), fat-free Cheddar cheese (FFC), rennet casein (RC); numbers $(0,24,48)$ following sample codes denote hours of storage. Color version available online. 
Table 3. Means separations for selected volatile compounds (ppb) identified on a ZB-5 column (Phenomenex, Torrance, CA) with significant F-statistics and interactions from

\begin{tabular}{|c|c|c|c|c|c|c|c|c|c|c|c|c|c|c|c|}
\hline Sample & Hexanal & Acetaldehyde & Heptanal & $\mathrm{DMS}^{1}$ & Diacetyl & $\begin{array}{c}2- \\
\text { Heptenal }\end{array}$ & $\mathrm{DMDS}^{1}$ & $\begin{array}{c}2-3- \\
\text { Pentanedione }\end{array}$ & $\begin{array}{c}2-4- \\
\text { Dimethylfuran }\end{array}$ & Nonanal & Octanal & $\begin{array}{c}2- \\
\text { Butanone }\end{array}$ & $\begin{array}{c}2- \\
\text { Heptanone }\end{array}$ & $\begin{array}{l}\text { 2-Methyl } \\
\text { butanal }\end{array}$ & $\begin{array}{c}\text { Z-4- } \\
\text { Heptenal }\end{array}$ \\
\hline Acid & $6.75^{\mathrm{c}}$ & $\mathrm{ND}^{2}$ & $0.85^{\mathrm{b}}$ & 0.33 & $0.17^{\mathrm{b}}$ & 0.01 & 3.70 & $0.03^{\mathrm{c}}$ & 0.44 & $0.018^{\mathrm{b}}$ & $0.021^{\mathrm{a}}$ & 8.48 & $0.06^{\mathrm{c}}$ & $0.21^{\mathrm{b}}$ & $2.30^{\mathrm{b}}$ \\
\hline Cheddar & $5.66^{\mathrm{c}}$ & ND & $0.99^{\mathrm{b}}$ & 0.40 & $3.87^{\mathrm{b}}$ & 0.01 & 4.53 & $0.04^{\mathrm{c}}$ & 0.35 & $0.004^{\mathrm{b}}$ & $0.008^{\mathrm{a}}$ & 6.89 & $0.04^{\mathrm{c}}$ & $0.21^{\mathrm{b}}$ & $0.82^{\mathrm{bc}}$ \\
\hline Fat-free Cheddar & $1.32^{\mathrm{c}}$ & ND & $0.25^{c}$ & 0.68 & $4.55^{\mathrm{b}}$ & 0.01 & 3.85 & $0.03^{c}$ & 0.99 & $0.005^{\mathrm{b}}$ & $0.006^{\mathrm{b}}$ & 18.62 & $0.025^{\mathrm{c}}$ & $0.21^{\mathrm{b}}$ & $0.62^{\mathrm{bc}}$ \\
\hline Cottage & $37.1^{\mathrm{b}}$ & $5.73^{\mathrm{b}}$ & $10.0^{\mathrm{a}}$ & 0.54 & $16.8^{\mathrm{ab}}$ & 0.15 & 4.07 & $5.68^{\mathrm{b}}$ & 0.84 & $0.125^{\mathrm{a}}$ & $0.006^{\mathrm{b}}$ & 7.64 & $0.80^{\mathrm{a}}$ & $0.47^{\mathrm{ab}}$ & $2.03^{\mathrm{bc}}$ \\
\hline Greek & $79.3^{\mathrm{a}}$ & $9.14^{\mathrm{a}}$ & $5.04^{\mathrm{b}}$ & 0.51 & $32.9^{\mathrm{a}}$ & 0.03 & 7.05 & $19.2^{\mathrm{a}}$ & 0.55 & $0.036^{\mathrm{ab}}$ & $0.004^{\mathrm{b}}$ & 9.75 & $0.43^{\mathrm{b}}$ & $0.61^{\mathrm{a}}$ & $27.1^{\mathrm{a}}$ \\
\hline Rennet & $0.94^{\mathrm{c}}$ & ND & $0.15^{\mathrm{b}}$ & 0.97 & $0.31^{\mathrm{b}}$ & 0.01 & 4.33 & $0.03^{\mathrm{c}}$ & 0.15 & $0.003^{\mathrm{b}}$ & $0.004^{\mathrm{b}}$ & 7.69 & $0.02^{\mathrm{c}}$ & $0.22^{\mathrm{b}}$ & $0.55^{\mathrm{c}}$ \\
\hline Time-0 & $14.3^{\mathrm{c}}$ & 9.16 & 2.39 & 0.33 & 11.4 & 0.02 & 4.33 & $5.44^{\mathrm{a}}$ & 0.24 & 0.015 & 0.009 & 9.81 & 0.27 & $0.20^{\mathrm{b}}$ & $1.77^{\mathrm{b}}$ \\
\hline Time-24 & $27.3^{\mathrm{b}}$ & 7.15 & 3.25 & 0.68 & 10.1 & 0.03 & 4.60 & $4.98^{\mathrm{b}}$ & 0.65 & 0.017 & 0.01 & 7.05 & 0.28 & $0.33^{\mathrm{ab}}$ & $7.69^{\mathrm{a}}$ \\
\hline Time-48 & $36.2^{\mathrm{a}}$ & 6.00 & 4.59 & 0.65 & 10.8 & 0.09 & 5.28 & $4.55^{\mathrm{c}}$ & 0.51 & 0.08 & 0.012 & 7.42 & 0.26 & $0.42^{\mathrm{a}}$ & $7.23^{\mathrm{a}}$ \\
\hline $\begin{array}{l}\text { Whey-Acid } \\
\times \text { Time-0 }\end{array}$ & $3.14^{\mathrm{cd}}$ & ND & $0.51^{\mathrm{d}}$ & 0.17 & $0.06^{\mathrm{b}}$ & 0.01 & 4.76 & $0.05^{\mathrm{f}}$ & $0.14^{\mathrm{b}}$ & $0.007^{\mathrm{b}}$ & $0.005^{\mathrm{b}}$ & 8.31 & $0.05^{\mathrm{b}}$ & ND & $1.68^{\mathrm{c}}$ \\
\hline $\begin{array}{l}\text { Whey-Acid } \\
\times \text { Time- } 24\end{array}$ & $5.00^{c}$ & ND & $0.91^{\mathrm{cd}}$ & 0.12 & $0.08^{\mathrm{b}}$ & 0.01 & 2.67 & $0.02^{\mathrm{f}}$ & $0.10^{\mathrm{b}}$ & $0.010^{\mathrm{b}}$ & $0.005^{\mathrm{b}}$ & 8.65 & $0.07^{\mathrm{b}}$ & $0.32^{\mathrm{bc}}$ & $2.84^{\mathrm{C}}$ \\
\hline $\begin{array}{l}\text { Whey-Acid } \\
\times \text { Time- } 48\end{array}$ & $12.1^{\mathrm{c}}$ & ND & $1.12^{\mathrm{cd}}$ & 0.71 & $0.37^{\mathrm{b}}$ & 0.01 & 3.66 & $0.02^{\mathrm{f}}$ & $1.09^{\mathrm{ab}}$ & $0.038^{\mathrm{b}}$ & $0.008^{\mathrm{ab}}$ & 8.47 & $0.07^{\mathrm{b}}$ & $0.32^{\mathrm{bc}}$ & $2.39^{\mathrm{c}}$ \\
\hline $\begin{array}{l}\text { Whey-Cheddar } \\
\times \text { Time- } 0\end{array}$ & $3.78^{\mathrm{cd}}$ & ND & $0.15^{\mathrm{d}}$ & 0.10 & $1.25^{\mathrm{ab}}$ & 0.01 & 3.30 & $0.05^{\mathrm{f}}$ & $0.03^{\mathrm{b}}$ & $0.001^{\mathrm{b}}$ & $0.002^{\mathrm{b}}$ & 14.0 & $0.03^{\mathrm{b}}$ & $0.10^{\mathrm{bc}}$ & $0.26^{\mathrm{c}}$ \\
\hline $\begin{array}{l}\text { Whey-Cheddar } \\
\times \text { Time- } 24\end{array}$ & $5.77^{\mathrm{c}}$ & ND & $1.19^{\mathrm{bc}}$ & 0.75 & $4.71^{\mathrm{ab}}$ & 0.01 & 3.57 & $0.03^{\mathrm{f}}$ & $0.16^{\mathrm{b}}$ & $0.005^{\mathrm{b}}$ & $0.005^{\mathrm{b}}$ & 4.57 & $0.04^{\mathrm{b}}$ & $0.29^{\mathrm{bc}}$ & $1.76^{\mathrm{c}}$ \\
\hline $\begin{array}{l}\text { Whey-Cheddar } \\
\times \text { Time- } 48\end{array}$ & $7.42^{c}$ & ND & $1.64^{\mathrm{bc}}$ & 0.34 & $5.64^{\mathrm{ab}}$ & 0.02 & 6.71 & $0.03^{\mathrm{f}}$ & $0.87^{\mathrm{ab}}$ & $0.007^{\mathrm{b}}$ & $0.004^{\mathrm{b}}$ & 2.06 & $0.04^{\mathrm{b}}$ & $0.23^{\mathrm{bc}}$ & $0.44^{\mathrm{c}}$ \\
\hline $\begin{array}{l}\text { Whey-fat-free } \\
\text { Cheddar } \\
\times \text { Time-0 }\end{array}$ & $0.97^{\mathrm{d}}$ & ND & $0.02^{\mathrm{d}}$ & 0.89 & $5.90^{\mathrm{ab}}$ & 0.01 & 3.98 & $0.04^{\mathrm{f}}$ & $0.04^{\mathrm{b}}$ & $0.002^{\mathrm{b}}$ & $0.004^{\mathrm{b}}$ & 20.6 & $0.01^{\mathrm{b}}$ & $0.25^{\mathrm{bc}}$ & $0.45^{\mathrm{c}}$ \\
\hline $\begin{array}{l}\text { Whey-fat-free } \\
\text { Cheddar } \\
\times \text { Time-24 }\end{array}$ & $1.30^{\mathrm{d}}$ & ND & $0.28^{\mathrm{d}}$ & 0.42 & $4.03^{\mathrm{ab}}$ & 0.01 & 5.50 & $0.04^{\mathrm{f}}$ & $2.53^{\mathrm{a}}$ & $0.003^{\mathrm{b}}$ & $0.006^{\mathrm{b}}$ & 18.8 & $0.03^{\mathrm{b}}$ & $0.18^{\mathrm{bc}}$ & $0.93^{\mathrm{c}}$ \\
\hline $\begin{array}{l}\text { Whey-fat-free } \\
\text { Cheddar } \\
\times \text { Time-48 }\end{array}$ & $1.68^{\mathrm{d}}$ & ND & $0.47^{\mathrm{d}}$ & 0.74 & $3.73^{\mathrm{ab}}$ & 0.02 & 2.07 & $0.02^{\mathrm{f}}$ & $0.39^{\mathrm{ab}}$ & $0.010^{\mathrm{b}}$ & $0.007^{\mathrm{ab}}$ & 16.5 & $0.03^{\mathrm{b}}$ & $0.19^{\mathrm{bc}}$ & $0.49^{\mathrm{c}}$ \\
\hline $\begin{array}{l}\text { Whey-Cottage } \\
\times \text { Time-0 }\end{array}$ & $12.8^{\mathrm{bc}}$ & $8.44^{\mathrm{ab}}$ & $8.04^{\mathrm{abc}}$ & 0.60 & $19.6^{\mathrm{ab}}$ & 0.03 & 4.94 & $6.77^{\mathrm{d}}$ & $0.45^{\mathrm{ab}}$ & $0.044^{\mathrm{b}}$ & $0.014^{\mathrm{ab}}$ & 5.50 & $0.79^{\mathrm{a}}$ & $0.38^{\mathrm{bc}}$ & $1.23^{\mathrm{c}}$ \\
\hline $\begin{array}{l}\text { Whey-Cottage } \\
\times \text { Time-24 }\end{array}$ & $33.9^{\mathrm{bc}}$ & $5.48^{\mathrm{ab}}$ & $9.47^{\mathrm{ab}}$ & 0.32 & $14.4^{\mathrm{ab}}$ & 0.06 & 5.05 & $5.15^{\mathrm{e}}$ & $1.91^{\mathrm{a}}$ & $0.041^{\mathrm{b}}$ & $0.017^{\mathrm{ab}}$ & 6.91 & $0.81^{\mathrm{a}}$ & $0.51^{\mathrm{b}}$ & $1.96^{\mathrm{c}}$ \\
\hline $\begin{array}{l}\text { Whey-Cottage } \\
\times \text { Time- } 48\end{array}$ & $64.7^{\mathrm{ab}}$ & $3.28^{\mathrm{b}}$ & $12.5^{\mathrm{a}}$ & 0.69 & $16.3^{\mathrm{ab}}$ & 0.36 & 2.22 & $5.11^{\mathrm{e}}$ & $0.17^{\mathrm{b}}$ & $0.290^{\mathrm{a}}$ & $0.023^{\mathrm{a}}$ & 10.5 & $0.80^{\mathrm{a}}$ & $0.52^{\mathrm{b}}$ & $2.90^{\mathrm{c}}$ \\
\hline $\begin{array}{l}\text { Whey-Greek } \\
\times \text { Time-0 }\end{array}$ & $51.2^{\mathrm{abc}}$ & $9.87^{\mathrm{a}}$ & $3.13^{\mathrm{bc}}$ & 0.57 & $35.9^{\mathrm{a}}$ & 0.02 & 5.31 & $20.3^{\mathrm{a}}$ & $0.56^{6 \mathrm{ab}}$ & $0.019^{\mathrm{b}}$ & $0.020^{\mathrm{ab}}$ & 10.7 & $0.45^{\mathrm{ab}}$ & $0.29^{\mathrm{bc}}$ & $6.83^{\mathrm{b}}$ \\
\hline $\begin{array}{l}\text { Whey-Greek } \\
\times \text { Time-24 }\end{array}$ & $90.9^{\mathrm{a}}$ & $8.82^{\mathrm{ab}}$ & $4.55^{\mathrm{abc}}$ & 0.58 & $31.2^{\mathrm{ab}}$ & 0.04 & 7.23 & $19.7^{\mathrm{b}}$ & $0.90^{\mathrm{ab}}$ & $0.028^{\mathrm{b}}$ & $0.022^{\mathrm{a}}$ & 9.45 & $0.44^{\mathrm{ab}}$ & $0.51^{\mathrm{b}}$ & $37.4^{\mathrm{a}}$ \\
\hline $\begin{array}{l}\text { Whey-Greek } \\
\times \text { Time-48 }\end{array}$ & $95.7^{\mathrm{a}}$ & $8.73^{\mathrm{ab}}$ & $7.44^{\mathrm{abc}}$ & 0.40 & $31.5^{\mathrm{ab}}$ & 0.03 & 8.62 & $17.6^{c}$ & $0.18^{\mathrm{b}}$ & $0.060^{\mathrm{b}}$ & $0.021^{\mathrm{ab}}$ & 9.13 & $0.40^{\mathrm{ab}}$ & $1.02^{\mathrm{a}}$ & $37.0^{\mathrm{a}}$ \\
\hline $\begin{array}{l}\text { Whey-Rennet } \\
\times \text { Time-0 }\end{array}$ & $0.87^{\mathrm{d}}$ & ND & $0.09^{\mathrm{d}}$ & 0.19 & $0.35^{\mathrm{b}}$ & 0.01 & 3.33 & $0.05^{\mathrm{f}}$ & $0.03^{\mathrm{b}}$ & $0.003^{b}$ & $0.003^{\mathrm{b}}$ & 10.5 & $0.02^{\mathrm{b}}$ & $0.20^{\mathrm{bc}}$ & $0.19^{\mathrm{c}}$ \\
\hline $\begin{array}{l}\text { Whey-Rennet } \\
\times \text { Time-24 }\end{array}$ & $0.72^{\mathrm{d}}$ & ND & $0.13^{\mathrm{d}}$ & 1.60 & $0.23^{\mathrm{b}}$ & 0.01 & 4.49 & $0.03^{\mathrm{f}}$ & $0.17^{\mathrm{b}}$ & $0.002^{\mathrm{b}}$ & $0.004^{\mathrm{b}}$ & 5.66 & $0.02^{b}$ & $0.20^{\mathrm{bc}}$ & $1.28^{\mathrm{c}}$ \\
\hline $\begin{array}{l}\text { Whey-Rennet } \\
\times \text { Time-48 }\end{array}$ & $1.22^{\mathrm{d}}$ & ND & $0.22^{\mathrm{d}}$ & 1.13 & $0.36^{\mathrm{b}}$ & 0.02 & 5.17 & $0.01^{\mathrm{f}}$ & $0.23^{\mathrm{ab}}$ & $0.003^{\mathrm{b}}$ & $0.005^{\mathrm{b}}$ & 6.91 & $0.01^{\mathrm{b}}$ & $0.25^{\mathrm{bc}}$ & $0.18^{\mathrm{c}}$ \\
\hline
\end{tabular}


Biplot (axes F1 and F2: 68\%)

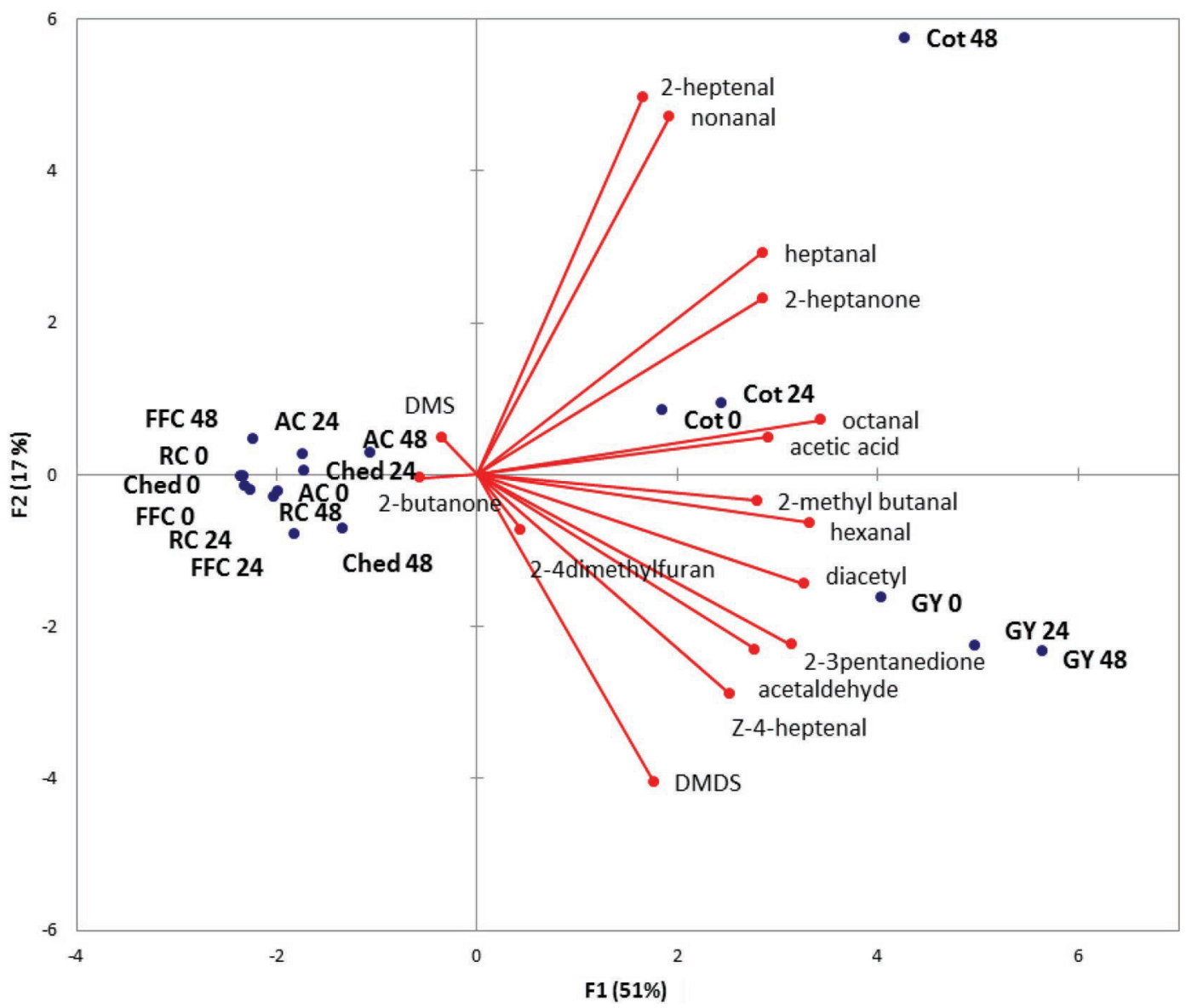

Figure 2. Principal component analysis biplot of volatile compound analysis results of liquid wheys: cottage cheese (Cot), Greek yogurt (GY), acid casein (AC), Cheddar cheese (Ched), fat-free Cheddar cheese (FFC), rennet casein (RC); numbers $(0,24,48)$ following sample codes denote hours of storage. DMS = dimethyl sulfide; DMDS = dimethyl disulfide. Color version available online.

current study made with thermophilic starter cultures and was more stable over $48 \mathrm{~h}$ than cottage cheese whey, which was made with mesophilic starter cultures. Gallardo-Escamilla et al. (2005) documented rancid and cheesy flavors in acid casein wheys, concurrent with results found in this study. Liquid storage time increased lipid oxidation compounds and off-flavors in all wheys, confirming that storage time in liquid form should be reduced in all (pasteurized) wheys before utilization.

This study also demonstrated that Greek yogurt whey, due to its low protein content, is not a viable source of

Table 4. Means separations for selected volatile free fatty acids (ppb) identified on a ZB-FFAP column (Phenomenex, Torrance, CA) with significant F-statistics from volatile analysis of wheys

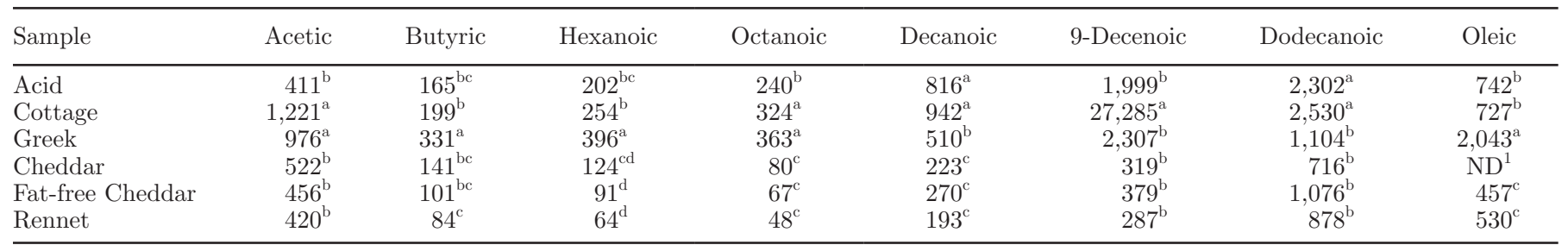

${ }^{\mathrm{a}-\mathrm{d}}$ Means in the same column not sharing common lettering are different $(P<0.05)$.

${ }^{1}$ Not detected. 
protein for concentration. Possible uses for Greek whey could be further fractionated into lactose and minerals. Frankowski et al. (2014) demonstrated that potassium and organic acids enhance the salty taste of sweet whey permeates. Greek yogurt whey has a composition similar to permeate but with higher acidity and may be a viable salt substitute. Cottage cheese and acid casein wheys also contained distinct potato/brothy and soapy flavors initially and after storage; therefore, evaluation of protein concentrate powders from these sources should be addressed with these flavors in mind. One possible emerging use of acid whey permeate following protein separation may be as a salt substitute. Whey permeate is currently a waste product and is often used as animal feed or fertilizer. These applications would provide a beneficial use for acid whey as a value-added ingredient in product applications.

This study served as a baseline comparison of the sensory, volatile, and compositional characteristics of fluid sweet and acid wheys. Previous studies have demonstrated that culture addition, cheese type, processing steps, and storage time all affect the flavor of liquid whey and subsequent whey powder (Gallardo-Escamilla et al., 2005; Liaw et al., 2010; Whitson et al., 2010, 2011; Campbell et al., 2011b). The current study confirmed these previously noted differences in flavor and flavor stability of Cheddar and Mozzarella wheys and compared them with Greek yogurt, cottage cheese, and acid and rennet wheys. Cottage cheese and acid casein wheys behaved similarly to Cheddar, with increases in volatile aldehyde composition and concurrent increases in off-flavor intensity with storage. Greek yogurt was the most stable of the acid wheys, whereas rennet casein was the most stable of the sweet wheys. Rennet casein produced a mild-flavored whey that showed little change in flavor over storage, and rennet casein whey has good potential for use as a source of whey protein ingredients. This study provides a platform for increased evaluation of applications for nontraditional wheys and acid wheys.

\section{ACKNOWLEDGMENTS}

Funding was provided in part by the National Dairy Council (Rosemont, IL) and the New York State Milk Promotion Board (Albany). The use of trade names does not imply endorsement nor lack of endorsement by those mentioned.

\section{REFERENCES}

AOAC International. 2000. Official Methods of Analysis. 17th ed. AOAC International, Gaithersburg, MD.
AOAC International. 2007. Official Methods of Analysis. 18th ed. AOAC International, Washington, DC.

Barbano, D. M., and J. M. Lynch. 1992. Crude and protein nitrogen bases for protein measurement and their impact on current testing accuracy. J. Dairy Sci. 75:3210-3217.

Campbell, R. E., R. E. Miracle, and M. A. Drake. 2011a. The effect of starter culture and annatto on the flavor and functionality of whey protein concentrate. J. Dairy Sci. 94:1185-1193.

Campbell, R. E., R. E. Miracle, P. D. Gerard, and M. A. Drake. 2011b. Effects of starter culture and storage on the flavor of liquid whey. J. Food Sci. 76:S354-S361.

Carunchia Whetstine, M. E., A. E. Croissant, and M. A. Drake. 2005. Characterization of dried whey protein concentrate and isolate flavor. J. Dairy Sci. 88:3826-3839.

Desai, N. T., L. Shepard, and M. A. Drake. 2013. Sensory properties and drivers of liking for Greek yogurts. J. Dairy Sci. 96:7454-7466.

Drake, S. L., P. D. Gerard, and M. A. Drake. 2009. Comparison of two methods to explore consumer preferences for Cottage cheese. J. Dairy Sci. 92:5883-5897.

Evans, J., J. Zulewska, M. Newbold, M. A. Drake, and D. M. Barbano. 2010. Comparison of composition and sensory properties of $80 \%$ whey protein and milk serum protein concentrates. J. Dairy Sci. 93:1824-1843.

Frankowski, K. M., R. E. Miracle, and M. A. Drake. 2014. The role of sodium in the salty taste of permeate. J. Dairy Sci. 97:5356-5370.

Gallardo-Escamilla, F. J., A. L. Kelly, and C. M. Delahunty. 2005. Sensory characteristics and related volatile flavor compound profiles of different types of whey. J. Dairy Sci. 88:2689-2699.

Hill, A. R., D. H. Bullock, and D. M. Irvine. 1985. Composition of cheese whey: Effect of $\mathrm{pH}$ and temperature of dipping. Can. Inst. Food Sci. Technol. J. 18:53-57.

Jervis, M. G., T. J. Smith, and M. A. Drake. 2015. The influence of solids concentration and bleaching agent on bleaching efficacy and flavor of sweet whey powder. J. Dairy Sci. 98:2294-2302.

Jervis, S. M., R. Campbell, K. L. Wojciechowski, E. A. Foegeding, M. A. Drake, and D. M. Barbano. 2012. Effect of bleaching whey on sensory and functional properties of $80 \%$ whey protein concentrate. J. Dairy Sci. 95:2848-2862.

Kandler, O. 1983. Carbohydrate metabolism in lactic acid bacteria. Antonie Van Leeuwenhoek 49:209-224.

Karagül-Yüceer, Y., M. A. Drake, and K. R. Cadwallader. 2003a. Aroma-active components of liquid cheddar whey. J. Food Sci. 68:1215-1219.

Karagül-Yüceer, Y., K. Vlahovich, M. A. Drake, and K. Cadwallader. 2003b. Characteristic aroma components of rennet casein. J. Agric. Food Chem. 51:6797-6801.

Kosikowski, F. V., and V. V. Mistry. 1997. Whey and whey foods. Pages 422-449 in Cheese and Fermented Milk Foods. Vol. 1. 3rd ed. F. V. Kosikowski LLC, Westport, CT.

Liaw, I. W., H. Eshpari, P. S. Tong, and M. A. Drake. 2010. The impact of antioxidant addition on flavor of Cheddar and Mozzarella whey and Cheddar whey protein concentrate. J. Food Sci. 75:C559-C569.

Liaw, I. W., R. E. Miracle, S. M. Jervis, M. A. D. Listiyani, and M. A. Drake. 2011. Comparison of the flavor chemistry and flavor stability of Mozzarella and Cheddar wheys. J. Food Sci. 76:C1188C1194.

Mahajan, S. S., L. Goddik, and M. C. Qian. 2004. Aroma compounds in sweet whey powder. J. Dairy Sci. 87:4057-4063.

Maragkoudakis, P., C. Miaris, P. Rojez, N. Manalis, F. Magkanari, G. Kalantzopoulos, and E. Tsakalidou. 2006. Production of traditional Greek yoghurt using Lactobacillus strains with probiotic potential as starter adjuncts. Int. Dairy J. 16:52-60.

McAuliffe, O., C. Hill, and R. P. Ross. 1999. Inhibition of Listeria monocytogenes in Cottage cheese manufactured with lacticin 3147-producing starter culture. J. Appl. Microbiol. 86:251-256.

Meilgaard, M. C., G. V. Civille, and B. T. Carr. 2007. The Spectrum $^{\text {TM }}$ descriptive analysis method. Pages 189-253 in Sensory Evaluation Techniques. CRC Press, Boca Raton, FL. 
NIST. 2005. NIST Wiley Registry: NIST Mass Spectral Library. 8th ed. Wiley, Hoboken, NJ.

Oltman, A. E., K. Lopetcharat, E. Bastian, and M. A. Drake. 2015. Identifying key attributes for protein beverages. J. Food Sci. 80:S1383-S1390

Tomaino, R. M., L. G. Turner, and D. K. Larick. 2004. The effect of Lactococcus lactis starter cultures on the oxidative stability of liquid whey. J. Dairy Sci. 87:300-307.

Turhan, K. N., and M. R. Etzel. 2004. Whey protein isolate and alphalactalbumin recovery from lactic acid whey using cation-exchange chromatography. J. Food Sci. 69:FEP66-FEP70.

Upreti, P., L. L. McKay, and L. E. Metzger. 2006. Influence of calcium and phosphorous, lactose and salt-to-moisture ratio on Cheddar cheese quality: Changes in residual sugars and water-soluble organic acids during ripening. J. Dairy Sci. 89:429-443.

Vandendool, H., and P. D. Kratz. 1963. A generalization of retention index system including linear temperature programmed gas-liquid partition chromatography. J. Chromatogr. 11:463-471.
Varnam, A. H., and J. P. Sutherland. 1994. Dairy protein products. Pages 159-182 in Milk and Milk Products-Technology, Chemistry and Microbiology. Chapman \& Hall, New York, NY.

Vasbinder, A. J., and C. G. de Kruif. 2003. Casein-whey protein interactions in heated milk: The influence of $\mathrm{pH}$. Int. Dairy J. 13:669-677.

Whitson, M. E., R. E. Miracle, E. Bastian, and M. A. Drake. 2011 Effect of liquid retentate storage on flavor of spray-dried whey protein concentrate and isolate. J. Dairy Sci. 94:3747-3760.

Whitson, M. E., R. E. Miracle, and M. A. Drake. 2010. Sensory characterization of chemical components responsible for cardboard flavor in whey protein. J. Sens. Stud. 25:616-636.

Wong, N. P., D. E. LaCroix, and F. E. McDonough. 1978. Minerals in whey and whey fractions. J. Dairy Sci. 61:1700-1703.

Wright, B. J., S. E. Zevchak, J. M. Wright, and M. A. Drake. 2009 Impact of agglomeration on flavor and flavor stability of whey proteins. J. Food Sci. 74:S17-S29. 